\title{
Maxillary Sinus Cancer pNO TNM Finding v6 and v7
}

National Cancer Institute

\section{Source}

National Cancer Institute. Maxillary Sinus Cancer pNO TNM Finding v6 and v7. NCI

Thesaurus. Code C65025.

Maxillary sinus cancer with no metastasis to regional lymph nodes. (from AJCC 6th and 7th Eds.) 